\title{
Sexual Abuse in Adolescents. Is it still happening?
}

\author{
Wulan Aprida Choirunnisa ${ }^{1}$, Herman Nirwana ${ }^{1}$, Syahniar $^{1}$ \\ ${ }^{1}$ Universitas Negeri Padang, Padang-Indonesia \\ *Corresponding author, e-mail: wulanaprida@gmail.com
}

\begin{abstract}
Sexual harassment is increasingly prevalent. This is a concern because most sex offenders are teenagers. Sexual harassment committed by adolescents is related to the psychological development they are undergoing. Adolescence is a transitional period between children and adults characterized by ongoing processes of change in biological, psychological and sociological terms. Adolescent students live their lives in school throughout the day, if calculated spending about 7 hours/day at school This study aims to describe the sexual abuse behavior of adolescents. The research sample consisted of 182 vocational students who were selected by the proportional random sampling technique. The instrument used was a scale of sexual harassment behavior. The research instrument was tested for validity and reliability The data analysis in this study used a quantitative approach with descriptive methods. The results showed that the acts of adolescent sexual harassment, in general, were in the high category of 76 students (42\%). The implications of this study are as a basis for counselors to prevent acts of teenage sexual harassment in schools.
\end{abstract}

Keywords: Sexual Harassment, Youth, Counseling Guidance
Received December 27 ${ }^{\text {th }}, 2019$; Revised January $2^{\text {nd }}, 2020$;

Accepted January $28^{\text {th }}, 2020$;

Published February $10^{\text {th }}, 2020$
Conflict of Interest Disclosures: The authors declare that they have no significant competing financial, professional or personal interests that might have influenced the performance or presentation of the work described in this manuscript.

How to Cite: Choirunnisa, W.A., Nirwana, H., Syahniar, S. (2020). Sexual Abuse in Adolescents. Is it still happening? Jurnal Aplikasi IPTEK Indonesia, 4 (1): pp. 32-36, DOI: $10.24036 / 4.14339$ 


\section{Introduction}

Acts of sexual harassment among adolescents are increasing, which is shown by sexual violence is increasingly rampant. Sexual crimes that occur can be classified into fifteen groups, namely: (1) rape, (2) sexual intimidation including threats or attempted rape, (3) sexual harassment, (4) sexual exploitation, (5) trafficking of women for sexual purposes, (6) forced prostitution, (7) sexual slavery, (8) forced marriage, including divorce, (9) forced pregnancy, (10) forced abortion, (11) forced contraception and sterilization, (12) sexual torture, (13) ) inhuman and sexual nuanced punishment, (14) traditional sexual nuanced practices that endanger or discriminate against women, and (15) sexual control (Komnas Perempuan, 2015).

Based on acts of sexual crimes among Indonesian children from one year to the next it tends to increase. The National Commission for Child Protection (KPAI) (2014) found that from 2014 to 2019 there were $21,869,797$ cases of violations of the rights of children, amounting to $42-58 \%$ of these violations were sexual crimes. Victims of sexual crimes against children have increased every year, marked in $201442 \%$ of sexual crimes occurred, 2015 occurred $58 \%$ of sexual crimes, and 2016 occurred $62 \%$ of sexual crimes, in 2017 there was a fairly high increase with $62 \%$ of sexual crimes. While in 2018 (January-April), there were 600 cases or 876 victims, and 137 cases of child perpetrators.

The National Commission for Child Protection (KPAI) states that from 2013 to 2019 the number of victims of sexual harassment rose by $100 \%$ both victims and perpetrators (Hendrian, 2019). When explored further, data from the Central Statistics Agency (BPS) (2019) shows 369 incidents relating to sexual crimes. South Sulawesi Province as many as 306 incidents. The provinces with the fewest incidents were DI Yogyakarta and Papua Provinces with 43 events and 10 events respectively. This incident shows that sexual crimes against children in the West Sumatra region can be categorized as increasing when compared to other Provinces in Indonesia.

Complaints of cases of child abuse increased from 2014 to 2015. In 2016 there were 30 cases of children being victims of sexual abuse, of which there were 14 perpetrators who were teenagers. Furthermore, in 2017 there were 37 cases of children victims of sexual harassment, among these cases there were 17 perpetrators who were teenagers. In 2018 there were 51 cases of sexual harassment, out of 51 cases there were 22 perpetrators who were teenagers. Child abuse is almost evenly distributed in all urban or peripheral areas (KPAI, 2019). Cases of sexual harassment in the Province of West Sumatra are ranked 15th out of 34 provinces in Indonesia. The people of West Sumatra Province are famous for the slogan "Adat Basandi Syarak, Syarak Basandi Kitabullah". Therefore, this should get attention to reduce it (Refer to November 15, 2019).

Sexual harassment results psychologically to the victim, namely: (1) annoyance, anxiety, anger, stress to breakdown, (2) fear, frustration, helplessness, and withdrawal, (3) loss of self-confidence, (4) feeling guilty or feel himself as the cause, (5) personal hatred to generalize hatred towards the offender or those of the same sex as the offender (Kelly, 1998). Women who experience sexual abuse experience physical consequences, such as stomach disorders, spinal pain, eating disorders, sleep disorders and irritability. While the psychological effects felt include feelings of being insulted, threatened and helpless (Rumini \& Sundari, 2004).

Sexual harassment is experienced not only by children, adolescents and even adults who are often victims and perpetrators of sexual harassment. In principle, both women and men can be victims as well as perpetrators of sexual harassment. However empirical reviews show that the most common constellations are male perpetrators and female victims (Alaggia, 2004; Berdahl \& Moore, 2006; Cortina, Magley, Williams, \& Langhout, 2001; Diehl, Glaser, \& Bohner, 2014; McDaniels- Wilson \& Belknap, 2008).

Jurnal Aplikasi IPTEK Indonesia, Open Access, http://bk.ppj.unp.ac.id/index.php/aiptekin/index 
Sexual harassment 1s still controversial in several countries (Koen, 1989; Thompson \& Bouffard, 2003). Some individuals even choose not to question the abuse they receive (Koen, 1989). This is supported by the results of a survey which states that only $40 \%$ agree that law enforcement and strict sanctions against sexual harassment are needed (Ford \& McLaughlin, 1987; Margono, 2000). Though predictions from the theory of revictimization (Finkelhor \& Browne, 1985) that individuals with a personal history of sexual harassment or unwanted sexual experiences will be very sensitive to sexual behavior and so it is more likely than others to be sexual harassers (O'connor, Gutek, Stockdale, Geer, \& Melancon, 2004; O'Leary-Kelly, Bowes-Sperry, Bates, \& Lean, 2009).

Speaking of victims, sexual harassment often has psychological consequences. A study shows that the prevalence rate of psychological distress among students who have experienced sexual abuse is $63 \%$ (Mamaru, Getachew, \& Mohammed, 2015). Sexual harassment is also associated with a variety of negative psychosocial and physical problems, such as self-injury (Chiodo, Wolfe, Crooks, Hughes, \& Jaffe, 2009; Gruber \& Fineran, 2007). Adolescents who experience sexual harassment have feelings of guilt, shame, and anxiety. As a result, they experience sleep disorders, turbances, eating disorders, drug and alcohol use, and are very at risk of mental health problems. This is because they have limited problemsolving skills compared to adults (Draucker \& Martsolf, 2008; Işik \& Kulakaç, 2015; Sexual \& Alliance, 2015).

\section{Method}

This research uses a quantitative approach with descriptive methods. This type of research is used to describe adolescent sexual harassment behavior. The research was conducted on Vocational High School students, West Sumatra, Indonesia. The sample in this study were 182 students of class XI selected by proportional random sampling technique. The instrument used was a section harassment instrument developed by researchers that were complemented by aspects: section harassment, verbal section harassment, visual section harassment, and physical section harassment. The instrument was developed using a Likert scale model consisting of 28 items. This research instrument has been tested for validity and reliability. Data were analyzed using the percentage formula (Sudjana, 2002).

\section{Results and Discussion}

\section{Results}

The results of the study in XI grade students of SMK Muhammadiyah 1 Padang city obtained an average of $42 \%$, a standard deviation of 24,398 with the lowest score of 28 , and the highest score of 140 . Categories of acts of sexual harassment were divided into five categories, namely very high, high, medium, low, and very low, description of sexual harassment can be seen in the following Table 1 .

Table 1.Adolescent Sexual Abuse $(\mathrm{n}=182)$

\begin{tabular}{|c|c|c|c|}
\hline Category & Skor & $\mathrm{f}$ & $\%$ \\
\hline $\begin{array}{c}\text { Very } \\
\text { High }\end{array}$ & $\geq 119$ & 32 & 17,5 \\
\hline High & $98-118$ & 76 & 42 \\
\hline Moderate & $76-97$ & 21 & 11,5 \\
\hline Low & $54-75$ & 27 & 15 \\
\hline $\begin{array}{c}\text { Very } \\
\text { Low }\end{array}$ & $\leq 53$ & 26 & 14 \\
\hline \multicolumn{2}{|l|}{ Jumlah total } & 182 & 100 \\
\hline
\end{tabular}


Table 1 above shows that teenage sexual harassment, in general, is in the high category, namely 76 students (42\%), while in the very high category, 32 students (17\%), in the moderate category, 21 students $(11.5 \%)$, in the low category is 27 students $(15 \%)$ and the very low category is 26 students (14\%). Sexual harassment committed by adolescents is related to the psychological development they are undergoing. Adolescence is a transitional period between children and adults characterized by ongoing processes of change in biological, psychological and sociological terms. This is supported by research that shows that the prevalence rate of psychological distress among students who have experienced sexual abuse is $63 \%$ (Mamaru, Getachew, \& Mohammed, 2015). Sexual harassment is also associated with a variety of negative psychosocial and physical problems, such as self-injury to adolescents themselves (Chiodo, Wolfe, Crooks, Hughes, \& Jaffe, 2009; Gruber \& Fineran, 2007). Adolescents who experience sexual harassment have feelings of guilt, shame, and anxiety. As a result, they experience sleep disorders, turbances, eating disorders, drug and alcohol use, and are very at risk of mental health problems. This is because they have limited problem-solving skills compared to adults (Draucker \& Martsolf, 2008; Işik \& Kulakaç, 2015; Sexual \& Alliance, 2015). Environmental factors provide a very large role in the formation of sexual behavior in adolescents. Abshor (2018) explains that the risk factors for sexual abuse at the individual level are the age and character of the child, family factors such as parents, siblings, bad parent-child interactions, and poor family functions. Then the risk factors for the environment in the form of status conditions.

\section{Discussion}

The results showed that the acts of teenage sexual harassment, in general, we're in the high category. The high rate of sexual harassment is caused because adolescence is a transition period between childhood to adulthood which is marked by ongoing processes of change in biological, psychological and sociological. Therefore, schools are a means for individuals to interact with each other. The individual itself is a means of learning about knowledge about social roles and norm boundaries. Problems with the quality of education are still inadequate.

Damarjati (2016) explained that Vocational High School (SMK) is one of the levels of senior secondary education that emphasizes skills (practice) in learning activities based on the chosen area of interest. Unpleasant school experiences may be a significant source of stress and reduce the quality of life for adolescents (Huebner \& McCullough, 2000). Huebner and McCullough's statement is supported by research by Fatimah (2010), the higher the stress experienced, the worse the impact and can affect the attitudes, interests, appearance, and behavior of adolescents.

Teenage students of Vocational High School (SMK) live their lives in school throughout the day, if calculated spending about 7 hours/day at school. While at school, the student follows a guidance and counseling service, one type of service provided is information services. Sari (2016) explains that counselors/counselors have the responsibility to prevent adolescents from sexual harassment, adolescents can become victims or become perpetrators of sexual harassment. One way to prevent sexual harassment from happening is to give students an understanding and knowledge of positive attitudes towards sexuality

Herdiana \& Sakalasastra's research (2012) explains the things that cause sexual abuse at the age of children and adolescents because they do not understand well about sex education and sexual abuse, about which behaviors should be avoided and about the consequences that will arise from immoral acts the immoral. In addition, children and adolescents tend not to have the strength to resist the wishes of the offender, plus the offender threatens the victim physically and psychologically.

\section{Conclusion}

Sexual harassment among adolescents is increasing, which is shown by sexual violence is increasingly rampant. Sexual crimes that occur can be classified into fifteen groups, namely: (1) rape, (2) sexual intimidation including threats or attempted rape, (3) sexual harassment, (4) sexual exploitation, (5) trafficking of women for sexual purposes, (6) forced prostitution, (7) sexual slavery, (8) forced marriage, including divorce, (9) forced pregnancy, (10) forced abortion, (11) forced contraception and sterilization, (12) sexual torture, (13) ) inhuman and sexual nuanced punishment, (14) traditional sexual nuanced practices that endanger or discriminate against women, and (15) sexual control.

Based on the results of research on acts of sexual harassment in SMK Muhammadiyah1 Padang City, in general, are in the high category. The variety of research results both in the respondent and in the aspect of sexual harassment is influenced by several factors not examined in this study. Therefore, further researchers should examine the influencing factors that influence teenage sexual harassment. The results of 
this study can be used as a reference for counselors to provide guidance and counseling services to students using a variety of creative/innovative counseling techniques/approaches.

\section{References}

Abshor, M. K., \& Psi, U. K. S. (2018). Faktor Risiko Terjadinya Pelecehan Seksual Pada Anak (Studi Kasus pada Anak Laki-laki Korban Pelecehan Seksual) (Doctoral dissertation, Universitas Muhammadiyah Surakarta).

Alaggia, R. (2004). Many ways of telling: Expanding conceptualizations of child sexual abuse disclosure. Child abuse \& neglect, 28(11), 1213-1227.

Angelina, D. Y., \& Matulessy, A. (2013). Pola Asuh Otoriter , Kontrol Diri dan Perilaku Seks Bebas Remaja SMK. Jurnal Bimbingan Konseling, 2(2), 173-182.

Arlyanti, R. (2012). Hubungan antara Kontrol Diri dengan Sikap terhadap Perilaku Seksual pada Remaja Karang Taruna. Jurnal Psikologi, 2(2), 170-183.

Azhar, S. K., Daharnis, \& Sukmawati, I. (2013). Persepsi Siswa tentang Layanan Informasi Kesehatan Reproduksi Remaja yang Diberikan Guru Bk SMAN 1 Kubung. Konselor, 2, 146-150.

Damarjati, I. H., Kusumawati, A., \& Mawardi, M. K. (2016). The influence of integrated marketing communication (IMC) on brand equity and purchase decision (survey on indosat-M3 customers among members of unit Aktivitas band Universitas Brawijaya class of 2014). Jurnal Administrasi Bisnis, 34(1), 29-37.

Draucker, C. B., \& Martsolf, D. S. (2008). Storying childhood sexual abuse. Qualitative health research, 18(8), 1034-1048.

Finkelhor, D., \& Browne, A. (1985). The traumatic impact of child sexual abuse: A conceptualization. American Journal of orthopsychiatry, 55(4), 530-541.

Floric, M., \& Broyles, M. (2012). Sexual abuse. Rosen Central.

Sakalasastra, P. P., \& Herdiana, I. (2012). Dampak psikososial pada anak jalanan korban pelecehan seksual yang tinggal di Liponsos anak surabaya. Jurnal Psikologi Kepribadian dan Sosial, 1(02), 68-72.

Indanah. (2016). Pelecahan Sexual pada Anak. Jurnal Psikologi Klinis Dan Kesehatan Mental, 7 No.1, 16-23.

Geldard, K. (2012). Konseling Remaja: Intervensi Praktis bagi Remaja Berisiko. (H. P. Soetjipto \& S. M. Soetjipto, Eds.). Yogyakarta: Pustaka Belajar.

Ghufron, M. N., \& Risnawati, R. (2014). Teori-teori Psikologi. Yogyakarta: Ar-ruzz Media.

Mamaru, A., Getachew, K., \& Mohammed, Y. (2015). Prevalence of physical, verbal and nonverbal sexual harassments and their association with psychological distress among Jimma university female students: A cross-sectional study. Ethiopian journal of health sciences, 25(1), 29-38.

Marrylee, F., \& Matthew, B., F. (20142. The Lifetime Prevalence of Child Sexual Abuse and Sexual Assault Assessed in Late Adolescence. Journal of Adolescent Health, 1-5. https://doi.org/10.1016/j.jadohealth.2013.12.026.

Novrialdy, E. (2019). Kecanduan game online pada remaja: Dampak dan pencegahannya. Buletin Psikologi, 27(2), 148-158

Novrialdy, E., Nirwana, H., \& Ahmad, R. (2019). High School Students Understanding of the Risks of Online Game Addiction. Journal of Educational and Learning Studies, 2(2), 113-119.

O'Kelly, M. E., \& Bryan, D. L. (1998). Hub location with flow economies of scale. Transportation Research Part B: Methodological, 32(8), 605-616.

O'Leary-Kelly, A. M., Bowes-Sperry, L., Bates, C. A., \& Lean, E. R. (2009). Sexual harassment at work: A decade (plus) of progress. Journal of Management, 35(3), 503-536.

Rumini, S., \& Sundari, S. (2004). Perkembangan anak dan remaja. Jakarta: Rineka Cipta.

Sudjana,N.(2002).Dasar-dasarProsesBelajarMengajar.Bandung:SinarBaruAlgensido Offset.

Sugiyono. (2016). Metode Penelitian \& Pengembangan (Research and Development) (2nd ed.). Bandung: Alfabeta.

Sukardi. (2008). Metodologi Penelitian Pendidikan, Kompetensi dan Praktiknya. Jakarta: Bumi Aksara.

Sundari, S., \& Rumini, S. (2004). Perkembangan anak dan remaja. Jakarta: PT Asdi Mahasatya.

Wahyuni, S. (2016). Qualitative research method: Theory and practice 2nd edition. 